\author{
Witold Zalewski \\ Uniwersytet Papieski Jana Pawta II w Krakowie \\ Międzyuczelniany Instytut Muzyki Kościelnej
}

\title{
Polska twórczość organowa zainspirowana pieśnią kościelną w liturgii Kościoła rzymskokatolickiego, cz. I
}

Znajomość literatury organowej rodzimych kompozytorów nadal pozostawia wiele do życzenia. Współcześni organiści kościelni, jeśli już wykonują solową muzykę organową w liturgii, sięgają często po utwory wielkich mistrzów europejskich, zapominając o polskim skarbcu muzyki religijnej. Trafnym spostrzeżeniem ujmującym istotę stanu wiedzy większości młodych (i nie tylko młodych) organistów na temat polskiej muzyki organowej wydaje się znane powiedzenie „cudze chwalicie, swego nie znacie”.

Dlaczego polska religijna literatura organowa jest tak ważna dla współczesnego muzyka kościelnego?

Z pewnością dlatego, że w liturgii Kościoła rzymskokatolickiego „bardzo pożądane będą” (czytaj: sa) „kompozycje oparte na motywach pieśni kościelnych”.

Pieśń kościelna już od XVI wieku wykorzystywana była przez kompozytorów polskich jako materiał melodyczny komponowanych przez nich utworów organowych. Pierwsze z takich kompozycji powstawały poprzez adaptację utworów wokalnych na instrument klawiszowy. „Jak wskazują badania, autorzy tych intawolacji instrumentalnych skupiają się głównie na "prostym zapisie przeniesień utworów wokalnych na instrument klawiszowy»"2.

Tabulatura Jana z Lublina z roku 1540 jest najwcześniejszym znanym polskim źródłem muzyki organowej ${ }^{3}$ oraz najobszerniejszym XVI-wiecznym źródłem mu-

1 A. Zając, Wybrane aspekty postugi organisty w spoteczności parafialnej, [w:] Muzyka organowa dzisiaj. Rola i zadanie organisty w Kościele, Kraków 2008, s. 81 (Pro Musica Sacra, 5).

2 K. Morawska, Historia muzyki polskiej. Renesans 1500-1600, Warszawa 1996, s. 300; cytuję za: T. Przybylski, Polska pieśn kościelna w twórczości organowej kompozytorów od XVI wieku do Mieczystawa Surzyńskiego, [w:] Organy i muzyka organowa, X, Gdańsk 1997, s. 136 (Prace Specjalne, 54).

3 Zob. J. Erdman, Organy, Warszawa 1989, s. 101. 
zyki organowej w Europie ${ }^{4}$. Zawiera ona 260 kart z pokaźną liczbą transkrypcji utworów wokalnych, rodzimych i obcych kompozytorów, w tym także utwory na organy solo. Są to: preludia, opracowania pieśni kościelnych i melodii chorałowych, a także tańce. $Z$ ciekawszych utworów ww. tabulatury wymienić należy przygrywki chorałowe: Ave Jerarchia autorstwa Mikołaja z Krakowa oraz anonimową Colenda - Nuż my dziatki zaśpiewajmy. Obie kompozycje znajdują się w zbiorze Dawna polska muzyka organowa, wydanym przez PWM w roku 1968 (red. J. Grubich, Kraków 1968). Zaznaczyć jednak należy, iż większość zbiorów nutowych wydanych w II połowie poprzedniego stulecia jest obecnie trudno dostępna; pozycje te (rzadko już w komplecie) znajdują się bądź w bibliotekach muzycznych, bądź w prywatnych zbiorach niektórych organistów.

Obszernym zbiorem kompozycji opartych na polskich pieśniach kościelnych jest krakowska Tabulatura klasztoru Św. Ducha z roku 1548. Znajdujące się tam preludium Tantum Ergo Sacramentum, osnute na melodii pieśni eucharystycznej, przypomniane zostało przez Jerzego Gołosa w jego dodatku nutowym dołączonym do rozprawy pt. Polskie organy $i$ muzyka organowa, wydanej przez Instytut Wydawniczy Pax w 1972 roku. Można tam znaleźć kompozycje zaczerpnięte z innych XVI-wiecznych tabulatur jak Salve Regina Mater Misericordiae z Tabulatury Warszawskiego Towarzystwa Muzycznego (zwanej też Tabulatura Marcina Leopolity ${ }^{5}$ lub „łowicką" ${ }^{\prime}$ ) z ok. 1580 oraz fugę Diomedis (autorstwa polskiego kompozytora włoskiego pochodzenia Diomedesa Cato) z Tabulatury Jana Fischera z Moraga z ok. $1595^{7}$.

Do XVII-wiecznych zabytków muzyki polskiej należą Warszawska tabulatura organowa z II połowy wieku oraz Tabulatura pelplińska. Dla tej pierwszej los nie był łaskawy. Zbiór ten, cudem uratowany przez Aleksandra Polińskiego ${ }^{8}$ od niedoszłego spalenia, którego zamierzał dokonać wiejski organista z okolic Warszawy i przekazany Bibliotece Narodowej, spłonął jednak wraz z nią w wyniku działań wojennych w roku 1944. Na szczęście tabulatura ta została w latach 20. XX wieku odpisana prawie w całości przez muzykologa Adolfa Chybińskiego, a potem powtórnie przez jego magistranta Czesława Sikorskiego. Na podstawie odpisu tego ostatniego Jerzy Gołos opracował, a Ludowy Instytut Muzyczny w Łodzi wydał

4 J. Gołos, Z polskiej muzyki organowej XVI wieku, Kraków 1989, s. 50.

5 Zob. J. Erdman, Organy, dz. cyt., s. 102.

6 Zob. T. Przybylski, Polska pieśń kościelna..., dz. cyt., s. 136.

7 Z XVI-wiecznych tabulatur wymienić należy jeszcze Tabulaturę Gdańską z 1591 roku.

8 Aleksander Poliński (1845-1916), polski krytyk muzyczny i zasłużony zbieracz zabytków naszej przeszłości muzycznej. Zob. Poliński Aleksander, [w:] Podręczna encyklopedia muzyki kościelnej, opr. ks. G. Mizgalski, Poznań 1959, s. 382. 
w roku 1990 zachowaną cześć tabulatury. Najbardziej znaną kompozycją tego zbioru jest Preludium Jana Podbielskiego.

Obszerna Tabulatura pelplińska zawiera pokaźną liczbę transkrybowanych utworów. Cancon a 4 Andrzeja Rohaczewskiego należy wg Joachima Grubicha do najcenniejszych poloników Tabulatury organowej klasztoru cystersów w Pelplinie?.

Wśród zachowanych zbiorów XVIII-wiecznych należy wymienić Kancjonat Jadwigi Dygulskiej zachowany w sandomierskiej bibliotece seminarium duchownego oraz Kancjonat Teresy O. Fabiańskiej z klasztoru Klarysek w Nowym Sączu. Anonimowe kompozycje zawarte w tych zbiorach są raczej niewielkich rozmiarów. Jak podaje Tadeusz Przybylski, cytując Hieronima Feichta:

\begin{abstract}
W wieku XVIII, mimo że znana jest znaczna liczba organistów, to jednak zabytków muzyki organowej - w tym także opracowań pieśni kościelnych $-\mathrm{z}$ tego okresu nie posiadamy. Prawdopodobnie ich wcale wówczas nie było, skoro w tym czasie zamiast preludiowania na organach grywano sonaty, symfonie, adagia skomponowane na zespoły instrumentalne ${ }^{10}$.
\end{abstract}

Pod koniec wieku XVIII i w wieku XIX zauważalne staje się w Europie, a także w Polsce zeświecczenie muzyki organowej spowodowane m.in. wpływem szkoły neapolitańskiej. Elementy świeckie i operowe przenikają także do muzyki kościelnej o charakterze użytkowym. Faktura polifoniczna sukcesywnie bywa zastępowana przez homofoniczną fakturę fortepianową, coraz częściej rezygnuje się z żywych przebiegów rytmicznych na rzecz struktur powolnych, majestatycznych, a przez to uważanych za bardziej „religijne”. Polską muzykę organową XVIII i XIX wieku cechuje stosunkowo niski poziom artystyczny w porównaniu z osiagnięciami zarówno europejskimi, jak i rodzimymi w poprzednich wiekach (XVI i XVII). Do ówczesnej muzyki kościelnej przenikają wpływy niemieckie, przede wszystkim w postaci popularnych w Niemczech wstępów i zakończeń do pieśni (tzw. Vorspiele i Nachspiele). Kompozytorzy polscy tego okresu podejmują jedynie nieśmiałe próby uwolnienia polskiej muzyki organowej od obcych wpływów i naleciałości świeckich.

Gatunek utworów o przeznaczeniu liturgicznym reprezentuje 10 krótkich sonat Wacława Raszka, wydanych w Kancjonale muzyki kościelnej w roku 1825 w Warszawie. Na wymienienie zasługuje Andante Karola Kurpińskiego, zapisane

9 Zob. Dawna Polska muzyka organowa, dz. cyt., s. 55.

${ }^{10} \mathrm{H}$. Feicht, Dzieje polskiej muzyki religijnej w zarysie, [w:] Księga tysiaclecia katolicyzmu w Polsce, t. 2, red. M. Rechowicz, Lublin 1969, s. 424; cytuję za: T. Przybylski, Polska pieśń kościelna..., dz. cyt., s. 136-137. 
pod nr 15 w jego Pieśniach nabożnych, które ma formę pieśni z krótką kodą. Organista (kościoła ewangelickiego), August Freyer (1801-1883), jest autorem kilku zbiorów preludiów przeznaczonych do wykorzystania w kościele. Są to m.in.: „12 preludyj do używania przy nabożeństwach lub mszy czytanej lub 10 preludyj do używania przy nabożeństwach lub mszy żałobnej”. Jak podaje Jerzy Erdman w swojej książce Organy ${ }^{11}$, opusowane zbiory Freyera od nr 4-9, 11, 14, 17, 18 nie były wznawiane i dostępne są jedynie w dawniejszych wydaniach. Andante op. 5 Augusta Freyera znalazło się w dodatku nutowym do rozprawy Jerzego Gołosa Polskie organy i muzyka organowa. Tam także, obok wspomnianych utworów zaczerpniętych z tabulatur, znaleźć można kompozycje Karola Kurpińskiego, Franciszka Lessela, Ignacego Dobrzyńskiego, Józefa Krogulskiego, Antoniego Sokulskiego, Józefa Grabowskiego oraz Stanisława Moniuszki.

Stanisław Moniuszko (1819-1872), twórca Halki, jako organista kościoła uniwersyteckiego św. Jana w Wilnie komponował również użytkową muzykę organową. W dodatku nutowym Gołosa znajduje się jego preludium oparte na pieśni Idzie, idzie Bóg prawdziwy. Twórczość organowa Moniuszki zawarta została w dwóch zbiorach: Pieśni naszego Kościota na organy utożone i do grania do mszy czytanej przeznaczone oraz Nieszpory i pieśń ostrobramska ${ }^{12}$. Dwie kompozycję z tego ostatniego zbioru, Gorzkie żale i Kto się w opiekę, wydane zostały przez PWM jako Miniatury organowe nr 41. Natomiast preludia: Boga Rodzico, Salve Regina, Serdeczna Matko i Witaj, Święta zawarte zostały w Pieśniach Maryjnych wydanych przez Salezjańską Szkołę Organową w Szczecinie w roku 2004 (red. ks. Maciej Szczepankiewicz) ${ }^{13}$.

Warto pamiętać, że polska twórczość religijna stanowi dorobek wybitnych polskich organistów-wirtuozów, nierzadko świetnych improwizatorów, posiadających wieloletnią praktykę zawodową.

Bronisław Rutkowski (1898-1964) - znany polski organista, pedagog, krytyk muzyczny, dyrygent i kompozytor uważał, że: „Wartościową muzykę kościelną może stworzyć jedynie talent muzyczny, posiadający wiedzę i technikę kompozytorską, głęboko jednocześnie przejęty prawdami wiary oraz treścią i formą religii”'14. Wychodząc naprzeciw oczekiwaniom: począwszy od twórczości Augusta

${ }^{11} \mathrm{~J}$. Erdman, Organy, dz. cyt., s. 108.

12 Według Jerzego Gołosa oba zbiory wydane zostały przez PWM w Dzietach Stanistawa Moniuszki, seria Pieśni, t. 6.

${ }^{13} \mathrm{~W}$ zeszycie znajdują się ponadto: Matko Niebieskiego Pana Stefana Surzyńskiego, Zdrowaś Maryja Józefa Furmanika i Zdrowaś Maryja Tadeusza Jarzęckiego.

${ }^{14}$ B. Rutkowski, $Z$ zagadnień dzisiejszej muzyki kościelnej w Polsce, „Muzyka Kościelna” 10 (1935), nr 3-4, s. 33-34; cytuję za: R. Tyrała, Cecyliański ruch odnowy muzyki kościelnej na ziemiach polskich do 1939 roku, Kraków 2010, s. 82. 
Freyera poprzez Władysława Żeleńskiego, Gustawa Roguskiego, Mieczysława Surzyńskiego, Franciszka Walczyńskiego, zaczęła się rodzić wartościowa polska literatura organowa i to zarówno o charakterze koncertowym, jak i użytkowo-liturgicznym ${ }^{15}$.

Twórcami tej literatury byli w pierwszym rzędzie działający na wielu płaszczyznach muzycznych organiści kościelni, kompozytorzy, organizatorzy życia muzycznego i profesorowie wyższych uczelni. Do tego kręgu postaci zaliczyć należy: Władysława Żeleńskiego (1837-1921), Stefana Surzyńskiego (1855-1919), Mieczysława Surzyńskiego (1866-1924), Feliksa Nowowiejskiego (1877-1946), Walentego Deca (1851-1938), Wincentego Rychlinga (1841-1896), Kazimierza Garbusińskiego (1883-1945), Feliksa Rączkowskiego (1906-1989), Józefa Furmanika (1867-1953), Mariana Sawę (1937-2005), Jana Gawlasa (19011965) oraz duchownych: ks. Gustawa Roguskiego (1839-1921), ks. Józefa Surzyńskiego (1851-1919), ks. Franciszka Walczyńskiego (1952-1937), ks. Antoniego Chlondowskiego (1884-1963) oraz ks. Idziego Ogiermana-Mańskiego (1900-1966).

Autor niniejszej publikacji ma świadomość tego, że podejmując się próby prezentacji polskiej twórczości organowej, „nie można przeprowadzić całkiem ściśle podziału na muzykę użytkową (dydaktyczną i kościelną) oraz koncertową, ponieważ wśród utworów użytkowych spotykamy większe formy o dużych ambicjach artystycznych, grywane zarówno w kościele, jak i na sali koncertowej”"16. Myśląc o utworze użytkowym, mamy zwykle na uwadze mniejsze kompozycje, przewidziane do zastosowania podczas liturgii. Utwory takie, "przeważnie niewielkich rozmiarów i niestwarzające wykonawcom specjalnych problemów wykonawczych”, "tworzyli kompozytorzy należący do tzw. nurtu cecyliańskiego". Ich zwięzła konstrukcja często zawierała wewnętrzne kadencje, pozwalające w razie potrzeby przerwać utwór w dowolnej chwili i odpowiednio go zakończyć. Ulubionymi tematami takich kompozycji były melodie gregoriańskie oraz pieśni: adwentowe, bożonarodzeniowe, wielkopostne, wielkanocne i maryjne. Niewielkim zainteresowaniem kompozytorów cieszyły się natomiast pieśni eucharystyczne, przygodne lub inne; utwory napisane na tematy melodii tych pieśni stanowią jedynie margines. Utwory o przeznaczeniu liturgicznym nazywano

${ }^{15}$ K. Mrowiec, Kultura muzyczna i pieśń kościelna, [w:] Historia Kościota w Polsce, t. 2, cz. 1, Poznań-Warszawa 1979, s. 712-717; cytuję za: T. Przybylski, Gustaw Roguski (1839-1921), [w:] Zeszyty naukowe Akademii Muzycznej im. Stanistawa Moniuszki w Gdańsku, XXVII, Gdańsk 1988, s. 49.

${ }^{16} \mathrm{~J}$. Gołos, Polskie organy i muzyka organowa, Warszawa 1972, s. 203.

$17 \mathrm{~J}$. Erdman, Organy, dz. cyt., s. 110. 
najczęściej preludiami, choć były to także: fugetty, postludia, ricercary, fugi, kanony, tria lub pastorale.

Kompozycje o charakterze użytkowym tworzone na potrzeby liturgii w duchu odnowy cecyliańskiej zgodnie z instrukcją dotyczącą muzyki kościelnej zawartą w motu proprio Tra le solecitudini Piusa X z roku 1903 zdominowały twórczość polskich kompozytorów na przełomie wieków XIX i XX. Nieprzypadkowo: „Literatura organowa I połowy XX wieku w Polsce (zarówno ta opublikowania i nieopublikowana) składała się prawie wyłącznie z użytkowej muzyki kościelnej”18. Twórczość ta znalazła także swoich kontynuatorów w latach 60. i 70. XX wieku, a nawet później - pod koniec ubiegłego stulecia.

Prezentację twórczości organowej polskich kompozytorów żyjących i działających na przełomie XIX i XX wieku należy rozpocząć od Władysława Żeleńskiego (1837-1921). W roku 1881 wydał on 25 preludiów na organy op. 38. W przedmowie do wydania twórca wyjaśnia cel swojego przedsięwzięcia:

Głównym jednak zadaniem mej pracy jest rozbudzenie lepszego smaku w naszych organistach, którym przytoczone tu kościelne pieśni swojskie powinny być przypomnieniem, jakiemi skarbami melodyi mają do rozporządzenia właśnie w pieśniach kościelnych. Chciałbym ich zachęcić do szlachetniejszego nieco traktowania instrumentu, który niezawodnie jest jednym z najważniejszych czynników rozbudzenia zmysłu piękna w ludzie wiejskim.

Niektóre ze swoich kompozycji Żeleński oparł na pieśni kościelnej. Są to preludia: nr 14 - Andante con moto - na temat W żtobie leży, nr 21 - Quasi Allegretto - na temat Aniot pasterzom mówit, nr 23 - Andante - na temat, Kto sie w opiekę oraz nr 25 - Andante sostenuto - na temat Święty Boże. Inną kompozycją Żeleńskiego jest Prelude pastorale op. 68. Wydana została w 1914 roku w Paryżu. Zdaniem Jerzego Gołosa: „Jest to utwór znacznie odbiegający poziomem trudności i inwencji kompozytorskej od wyżej omawianych preludiów i tym samym ukazuje twórczość organową Żeleńskiego w nowym świetle” ${ }^{19}$. Przypomniana ona została przez Feliksa Rączkowskiego i Jerzego Gołosa w zbiorze $Z$ polskiej muzyki organowej XIX/XX wieku (Kraków 1981).

${ }_{18}$ T. Przybylski, Organistyka krakowska XVIII i XIX wieku oraz w latach międzywojennych XX wieku, [w:] Organy i muzyka organowa, XIII, Gdańsk 2006, s. 56 (Prace Specjalne, 71).

19 Zob. Stowo redakcyjne, [w:] Z polskiej muzyki organowej XIX i XX wieku, red. F. Rączkowski, J. Gołos, Kraków 1981, s. 90. 
„Twórczość organowa ks. Józefa Surzyńskiego (1851-1919) jest świadectwem przełomu, jaki dokonał się w drugiej połowie XIX wieku" ${ }^{20}$. Związany z Poznaniem, m.in. poprzez posługę organisty w tamtejszej katedrze, Józef Surzyński był gorącym orędownikiem cecyliańskiej odnowy muzyki kościelnej. Z zachowanej twórczości tego duchownego wymienić należy przede wszystkim dwa zbiory: Preludia organowe op. 8 (zeszyt I) i Preludia organowe op. 12 (zeszyt II), wydane w Poznaniu w 1893 roku przez J. Leitgebera, zawierające po 10 kompozycji w każdym zeszycie. Niektóre z nich oparte zostały na pieśniach kościelnych (np. Postludium op. $8 \mathrm{nr} 2$ - na temat Boże wieczny, Boże żywy, Postludium op. $8 \mathrm{nr}$ 5 - Gtos wdzięczny z nieba wychodzi i Postludium op. $12 \mathrm{nr} 4$-Aniot pasterzom mówit). Na szczególną uwagę zasługuje pozycja op. $8 \mathrm{nr} 4$ (Adagio) skomponowana do adwentowej melodii Zdrowaś bądź Maryja. Utwór ten już jako Przygrywka choratowa znalazł się także we wspomnianym zbiorze Feliksa Rączkowskiego i Jerzego Gołosa. W słowie redakcyjnym autorów tego wydania czytamy: „Staraliśmy się wybrać możliwie najbardziej atrakcyjne, choć mało znane lub zupełnie nieznane utwory" 21 .

Jedną z czołowych postaci ruchu cecyliańskiego był także ks. Franciszek Walczyński, ceniony w Europie kompozytor muzyki religijnej ${ }^{22}$. Najbardziej znaną jego kompozycją jest Adoratione. Quasi fantasia op. 110, pochodzące ze zbioru Orgel-Kompositionen aus alter und neuer Zeit, t. 4, s. 320-323, wydanego przez Otto Gaussa w Regensburgu w 1910 roku. Utwór ten, oparty na pieśni eucharystycznej Chwalmy niewystowiony, składający się z tematu i pięciu wariacji, doczekał się polskiego wydania w ww. zbiorze Rączkowskiego i Gołosa. Wśród wielu preludiów Walczyńskiego były i takie, w których wykorzystywał on melodie kolęd; dwanaście takich opracowań znajduje się w zbiorze Eatwe preludia kolędowe na organy lub harmonium op. 132 wydanym w Tarnowie przez Zygmunta Jelenia w 1931 roku. Inną ciekawą pozycją nutową zawierającą kompozycje oparte na kolędach jest wydany w Tarnowie w roku 1912 zbiór pt. In Natali Domini XXXV Praeludia pastorale organo vel harmonio op. 117. Najbardziej interesującą kompozycją tego zbioru jest Preludium nr 1 Wśród nocnej ciszy. Preludia organi op. 5 (Edition Gebethner \& Wolf nr 30, 1897 r.) są krótkimi, kilkunastotaktowymi utworami, wśród których Preludium nr 3 oparte zostało na pieśni eucharystycznej Chwalmy niewystowiony, Preludium nr 19 osnute zostało na melodii pieśni wielkopostnej Już Cię żegnam, najmilszy Synu, Preludium nr 31 nawiązuje do kolędy Wśród nocnej ciszy, a Preludium nr 36 do pieśni eucharystycznej $U d r z w i$,

\footnotetext{
${ }^{20} Z$ polskiej muzyki organowej XIX $i$ XX wieku, dz. cyt., s. 89.

${ }^{21} Z$ polskiej muzyki organowej XIX/XX wieku, , dz. cyt., s. 89.

${ }^{22}$ Zob. J. Erdman, Organy, dz. cyt., s. 110.
} 
Twoich stoję Panie. Zbiór Preludia op. 6 zawiera natomiast krótkie utwory organowe mające na celu opanowanie przez organistę tonacji durowych i molowych. $\mathrm{Na}$ wymienienie zasługuje dwuczęściowy zbiór utworów ks. Walczyńskiego pt. Praeludia organalia, wydany pod opusem 106 A i B. Część A, De Pasione Domini Nostri Jesu Christi, zawiera 20 utworów użytkowych przeznaczonych na okres wielkopostny. W niektórych z nich wykorzystane są takie melodie pieśni jak Wisi na krzyżu (Preludium nr 5), Ty, któryś gorzko na krzyżu umierat (Preludium nr 8), pobudka z Gorzkich Żali (Preludium nr 12), Stata Matka boleściwa (Preludium nr 16), Jezu Chryste, Panie mity (Preludium nr 17), a także hymn z Gorzkich żali (Preludium nr 18). Część B, De Resurrectione Domini Nostri Jesu Christi, zawiera natomiast 10 kompozycji wielkanocnych. Występują tam motywy pieśni: Wesoly nam dzień dziśs nastat (Preludium nr 2), Nie zna śmierci Pan żywota (Preludium nr 3), Otrzyjcie już tzy, ptaczacy (Preludium nr 6), Dziś Chrystus, Król wiecznej chwaty (Preludium nr 9). Na zbiór pt. Laudate Dominum in organo op. 17 składają się inwencje trzy- i czterogłosowe, opracowane w układzie 2 razy po 25 krótkich kompozycji, zawierających do trzech znaków przykluczowych. Wśród utworów czterogłosowych znajdujemy inwencję nr 13 opartą na melodii kolędy $W$ żtobie leży oraz inwencję nr 18 wykorzystującą melodię pieśni pasyjnej Ty, któryś gorzko na krzyżu umierat.

„Jednym z najbardziej znanych polskich organistów przełomu XIX i XX wieku był Mieczysław Surzyński (1866-1924). Dzieła organowe Surzyńskiego znajdowały wysoką ocenę we współczesnym świecie muzycznym. [...]. Duża części jego twórczości organowej związana jest z tzw. kierunkiem cecyliańskim”23. Najważniejszym dziełem Mieczysława Surzyńskiego, nazywanego „ojcem współczesnej organistyki polskiej oraz wskrzesicielem polskiej muzyki kościelnej”24 jest zbiór pt. Rok w pieśni kościelnej. Preludia organowe op. 42 na melodiach pieśni kościelnych osnute. Zbiór ten zawiera 59 utworów opartych na melodiach pieśni kościelnych, ułożonych tematycznie wg roku liturgicznego. Wydany po raz pierwszy w Warszawie w 1900 roku przez wydawnictwo Gebethner i Wolff25, wznowiony został w roku 1999 przez Wydawnictwo Karmelitów Bosych w Krakowie. Kompozycje te, zawarte w pięciu zeszytach, obejmują: 11 preludiów opartych na melodiach

${ }^{23}$ Chaconne op. 14. Improvisation ueber ein altes polnisches Kirchenlied. Improvisation für Orgel über ein altes polnisches Kirchenlied op. 38. Choral varié op. 50, hg. J. Erdman, Warszawa 2001.

${ }^{24}$ T. Przybylski, Polska pieśn kościelna w twórczości kompozytorów od XVI wieku do M. Surzyńskiego, dz. cyt., s 135.

${ }^{25}$ T. Przybylski, Polska pieśn kościelna w twórczości kompozytorów od XVI wieku do M. Surzyńskiego, dz. cyt., s. 144. 
adwentowych (zeszyt I), 13 utworów bożonarodzeniowych (z. 2), 13 utworów na tematach pieśni okresu Wielkiego Postu (z. 3), 14 preludiów na Wielkanoc, Zielone Świątki, na uroczystość Trójcy św. i Boże Ciało (zeszyt 4) oraz 8 pieśni opartych na melodiach maryjnych (zeszyt 5).

Mieczysław Surzyński zerwał z systemem niewolniczego trzymania się niezmienionej melodii. Swoje preludia osnute na polskich pieśniach kościelnych ogromnie ubogacił poprzez stosowanie wielości technik kompozytorskich, od prostej homofonii aż po skomplikowaną polifonię ${ }^{26}$.

Do opracowywania pieśni kompozytor wykorzystał różne gatunki muzyczne: ricercar (Boże wieczny, Boże żywy - zeszyt 1), fugę (Urząd zbawienia ludzkiego - zeszyt 1), kanon (Ludu mój, ludu - zeszyt 3), kanon podwójny (Jezu Chryste, Panie mity - zeszyt 3), trio (Wstat Pan Chrystus - zeszyt 4, Ciebie na wieki wychwalać będziemy - zeszyt 5, Idźmy tulmy się jak dziatki - zeszyt 5), preludium i fugę (Nie opuszczaj nas - zeszyt 5). Melodia tematyczna jako cantus firmus pojawia się tam w różnych głosach. Utwory występują w większości w przystępnych tonacjach (do czterech znaków przykluczowych), choć można spotkać też opracowania dużo trudniejsze, np.: Wesoty nam dzień dziś nastat w tonacji Des-dur, O Jezu, jakoś ciężko skatowany (w es-moll), Ludu mój ludu (w b-moll). W zbiorze zamieszczono też kilka utworów nieposiadających tytułu pieśni, takich jak: Intermezzo, Postludium (zeszyt 1) oraz Pastorale (zeszyt 2).

Zdaniem współczesnego organisty Juliana Gembalskiego omówiony wyżej zbiór Surzyńskiego stał się, obok Orgelbüchlein ${ }^{27}$ Jana Sebastiana Bacha, inspiracją dla twórczości organowej Jana Gawlasa ${ }^{28}$. Pośród 50 kompozycji tego śląskiego kompozytora większość stanowią preludia oparte na chorałach luterańskich ${ }^{29}$,

${ }^{26}$ Wstęp, [w:] T. Przybylski, Rok w pieśni kościelnej. Preludia organowe op. 42 na melodiach polskich pieśni osnute, Kraków 1999, s. 6.

27 Zamiarem Bacha było opracowanie 164 wybranych melodii chorałowych. Kompozytor zrealizował swój pomysł tylko fragmentarycznie, 46 małych opracowań chorałowych, podzielonych na 2 części (w pierwszej części znajdują się chorały ułożone według roku kościelnego, a w drugiej chorały katechizmowe) zawarł w zbiorze Orgelbüchlein. Pewną analogią do Orgelbüchlein Bacha (w sensie pomysłu) są zbiory preludiów: Rok w pieśni kościelnej. Preludia organowe op. 42 na melodiach polskich pieśni osnute Mieczysława Surzyńskiego, Preludia na organy bez pedatu Feliksa Rączkowskiego, Preludia na temat polskich pieśni kościelnych Tadeusza Machla i Preludia organowe na temat polskich pieśni kościelnych Mariana Sawy.

${ }^{28}$ Wieloletni organista kościoła Ewangelicko-Augburskiego w Cieszynie (1901-1965).

${ }^{29}$ Zob. M. Pilch, Jan Gawlas - śląski twórca ewangelickiej muzyki kościelnej, Wrocław 2008, s. 616. 
zawartych w zbiorze Miniatury organowe - choraty kościota Jezusowego w Cieszynie op. $14^{30}$. Odnaleźć w nich można oprócz opracowań melodii pieśni śpiewanych w kościele cieszyńskim także i te, które nawiązują do polskiej tradycji Kościoła katolickiego. Jako przykład posłużyć tu mogą kompozycje: Preludium nr 19 osnute na pieśni Jezu Chryste, Panie mity, Preludium nr 44 oparte na Bóg się rodzi, Preludium nr 45 będące opracowaniem kolędy $W$ żtobie leży i Preludium nr 46 skomponowane na motywach Gdy sie Chrystus rodzi. Jak podaje prof. Julian Gembalski, są to „krótkie, nieprzekraczające 50 taktów kompozycje, wszystkie są jednoczęściowymi polifonicznymi preludiami o przewadze faktury 4-głosowej, napisanymi na 2 manuały i pedal" 31 .

Stefan Surzyński (1855-1919) większość swojego życia zawodowego spędził w Tarnowie (1888-1913) i Lwowie (od 1913), gdzie był organistą i dyrygentem chórów katedralnych. Jest autorem zbioru 50 preludiów organowych Preludia na organy. Utwory oryginalne i na tematy pieśni kościelnych dla użytków organistów i zaktadów naukowych, z których 37 opartych jest na polskich pieśniach religijnych. W utworach tych „głównym założeniem miała być prostota formy i rezygnacja z kunsztownej techniki kontrapunktycznej na rzecz prostego czynnika harmonicznego, najczęściej w postaci figuracji melodycznej”32. Preludia Surzyńskiego, wydane pod jego redakcją przez oficynę wydawniczą Gebethnera $^{33}$, są dziś niestety niedostępne. Dwa utwory zamieszczone zostały w zbiorze Jerzego Gołosa - Mato znane polskie utwory organowe XIX/XX wieku Są to: preludium Ach, ja Matka tak żatosna oraz preludium nt. kolędy $\mathrm{Na} B o z \dot{e} \mathrm{Na}$ rodzenie. Ta druga kompozycja znajduje się również w dwutomowym zbiorze braci Stefana i Mieczysława Surzyńskich Pastoratki. Preludia na organy op. 63 (zeszyt 1) i Pastoratki. Preludia na organy op. 67 (zeszyt 2). Oba zeszyty zostały wznowione przez Wydawnictwo Karmelitów Bosych w Krakowie w roku 2000. We wstępie do tego wydania, opartego na przedwojennej edycji warszawskiej z roku 1909, napisano:

${ }^{30}$ Zbiór 40 preludiów organowych zawiera opracowania pieśni Kościoła Ewangelickiego. W skład tego zbioru wchodzą 34 utwory, znajdujące się w pierwszej części rękopisu kompozytora oraz przypuszczalnie 6 następnych kompozycji z drugiej jego części, będących już bez numeracji. Zob. J. Gembalski, Twórczość organowa Jana Gawlasa, [w:] Twórczość kompozytorów środowiska katowickiego, red. J. Bauman-Szulakowska, I. Bias, Katowice 1993, s. 99 (Zeszyty Naukowe. Akademia Muzyczna im. Karola Szymanowskiego w Katowicach, 26).

31 J. Gembalski, Twórczość organowa Jana Gawlasa, dz. cyt., s. 101.

32 T. Przybylski, Twórczość organowa Stefana Surzyńskiego (1855-1919), [w:] Organy i muzyka organowa, XI, Gdańsk 2000, s. 331 (Prace Specjalne, 54).

33 T. Przybylski, Twórczość organowa Stefana Surzyńskiego (1855-1919), dz. cyt., s. 329. 
Zbiór Pastoratek braci Surzyńskich imponuje zarówno liczbą wybranych kolęd, jak i wytrawnym opracowaniem. Przedstawiają one niewątpliwie i dzisiaj swoiste wartości artystyczne, które z powodzeniem mogą być eksponowane podczas liturgii po naszych kościołach w okresie Bożego Narodzenia $^{34}$.

W pierwszym zeszycie znajduje się 20 utworów, 8 skomponowanych zostało przez Stefana, pozostałą część stanowią opracowania jego brata. Z 18 preludiów zawartych w drugim zeszycie tylko dwa są autorstwa starszego z braci (nr 7 i 11). Opracowania Stefana Surzyńskiego z reguły wykorzystują (prezentuja) całą melodię pieśni na początku utworu, w dalszej części zaś opracowują ją wariacyjnie (np. Hej w dzień Narodzenia - zeszyt 1, Jezus malusieńki - zeszyt 2). Niekiedy kompozytor stosuje zmianę trybu tonacji (Przybieżeli do Betlejem - zeszyt 1) lub zmianę rytmu melodii ( $W$ żtobie leży, któż pobieżny, nr 9 - zeszyt 2). W jego utworach widoczne są cechy faktury fortepianowej, charakterystycznej dla XIX-wiecznych opracowań pieśni (np. Pastoratki nr 3 i 8 - zeszyt 1). Preludia Mieczysława Surzyńskiego są z reguły oparte na fakturze polifonicznej, co nie wyklucza zastosowania tam także stylu fortepianowego (Bóg się rodzi, moc truchleje nr 18 - zeszyt 1 lub Pastoratka nr 12 - zeszyt 2). Tylko niektóre utwory obydwu kompozytorów posiadają partię pedałową. Sześć kompozycji w obu zeszytach zbioru nosi nazwę Pastoratki, ponieważ nie wiążą się tematycznie z żadną kolędą.

Postępowy organista op. 23 to tytuł zbioru Szczepana Sieji (1883-1949), wydanego w Warszawie przez Edition Gebethner \& Wolff nr 90 w roku 1929. Zeszyt 1 (nie wiadomo, czy były następne) zawiera 30 preludiów dwu- i trzygłosowych, choć na stronie tytułowej określono je jako 30 Preludjów dwugłosowych. Piętnaście z nich służy nauce transpozycji (nad każdą kompozycją zamieszczone są dwie tonacje do wyboru, np. utwór w tonacji C-dur może być wykonany także w tonacji Cis-dur, utwór w tonacji D-dur alternatywnie w Des-dur, a utwór w tonacji e-moll - w es-moll itd.). Pod pewnymi względami jest to więc rodzaj „szkoły gry” na organach. Pozostałe preludia trzygłosowe nawiązują do twórczości użytkowej, popularnej w tym czasie w Europie. W tym samym duchu skomponowane zostały przez Sieję 64 Preludja organowe (bez pedału), nagrodzone na konkursie im. Mieczysława Surzyńskiego, ogłoszonym przez Warszawskie Towarzystwo Muzyczne w 1931 roku. Wydane zostały w dwóch zeszytach, op. 74 i op. 75, przez W. Maciaszczyka w Łodzi w 1931 roku. Wydaje się, że twórczość organowa Szczepana Sieji poza znaczeniem czysto użytkowym nie wykazuje jednak

34 Wstęp, [w:] T. Przybylski, Pastoratki. Preludia na organy op. 63, z. 1, Kraków 2000, s. 4. 
większych walorów artystycznych. Za najciekawsze dokonanie tego kompozytora można uznać kompozycję dedykowana Gustawowi Roguskiemu pt. Jezu Chryste, znajdującą się w trzecim zeszycie - Roku w pieśni kościelnej... Mieczysława Surzyńskiego, wydanego przez Gebethnera i Wolffa w Warszawie (prawdopodobnie w roku 1909).

Kazimierz Garbusiński (1883-1945) jest głównym autorem zbioru 100 Preludyj Dwu, trzy i wielogtosowych na organy wydanego w 1914 roku przez Wydawnictwo Muzyczne Bolesława J. Zalewskiego w Chicago. Pozycja ta, jak czytamy nad spisem treści, została opracowana i usystematyzowana w formie szkoły przez Kazimierza Garbusińskiego, Franciszka Przystała, Waleryana Stysia i Bolesława Wallek-Walewskiego. Zbiór ten zawiera 11 preludiów dwugłosowych, 19 trzygłosowych oraz 70 cztero- i wielogłosowych. Niektóre z nich oparte zostały na polskiej pieśni kościelnej (np. dwugłosowe preludium nr 9 na temat Kto się w opiekę, trzygłosowe nr 28 na temat Jezu Chryste, Panie mity oraz czterogłosowe nr 36 na temat kolędy Wśród nocnej ciszy). Niekiedy preludia są faktycznie fugami (Preludium alla fuga na temat Wstat Pan Chrystus nr 39) lub fughettami (Fughetta alla Bach na temat Adamie, ty Boży Kmieciu). Kazimierz Garbusiński jest także autorem wariacji na temat pieśni kościelnych z roku 1949. Dwie z nich znajdują się w zbiorze Mato znane polskie utwory organowe XIX/XX wieku, wydanym przez Jerzego Gołosa w roku 1990 w Warszawie ${ }^{35}$. Są to: siedmioczęściowe wariacje: Gaudium imensum na temat pieśni O niewystowione Szcześscie zajaśniato oraz Laudemus tantum sacramentum na temat pieśni eucharystycznej Chwalmy niewystowiony Sakrament uwielbiony. We wstępie do tego zbioru czytamy m.in.:

Niniejszy zbiór stanowi kontynuacje rozpoczętej w 1989 r. serii zeszytów poświęconych mniejszym formom polskiej muzyki organowej komponowanych dla potrzeb praktycznych i koncertowych w II połowie XIX wieku i z początkiem bieżącego stulecia, dostępnej jedynie w starych wydaniach $^{36}$.

Oprócz ww. wariacji w zbiorze Gołosa umieszczone zostały również: trzy inne kompozycje Garbusińskiego jak: Pastorale op. 14 nr 2, Pastorale op. 14 nr 7 i Improwizacja oraz jedna Fantazja op. 3 nr 15 autorstwa Franciszka Przystała.

Do najbardziej znanych polskich XX-wiecznych „szkół organowych” zaliczamy Szkote gry na harmonium Augusta Piechury (wydaną w Przemyślu po roku

\footnotetext{
${ }^{35}$ Zob. Przedmowa, [w:] Mato znane polskie utwory organowe XIX/XX wieku, red. J. Gołos, Warszawa 1990.

${ }^{36}$ Mato znane polskie utwory organowe XIX/XX wieku, dz. cyt., s. 1.
} 
1930) zawierającą wartościowe utwory Feliksa Nowowiejskiego, Idziego Mańskiego, Kazimierza Garbusińskiego, Franciszka Przystała i Augusta Piechury ${ }^{37}$ oraz wydaną przez Edition Geberthner \& Wolf pod nr 54 trzyczęściową Szkote na organy Henryka Makowskiego i Mieczystawa Surzyńskiego (wydaną ok. 1911 roku $^{38}$ ). Na szczególną uwagę zasługuje Preludium (nr 93, II cz.), będące kompozycją Gustawa Roguskiego (1839-1921). Twórczość tego kompozytora ma wartość głównie historyczną. Tadeusz Przybylski wymienia ponadto trzy inne utwory Gustawa Roguskiego oparte na pieśniach kościelnych, wydane w drugim zeszycie jego Preludiów organowych z roku $1902^{39}$. (Jerzy Gołos podaje rok 1865 jako datę powstania tych preludiów i Warszawę jako miejsce ich wydania ${ }^{40}$ ). Dwa z tych preludiów (nr 21 i 22) o fakturze homofonicznej (każde zawiera temat w postaci harmonicznej z 3 wariacjami) osnute są na kolędach Aniot Pasterzom i Hej, w Dzień Narodzenia (w taktach 47-53 tego utworu pojawia się także melodia kolędy $W \dot{z}$ tobie leży). Trzecie preludium w tonacji a-moll wg Gołosa jest opracowaniem pieśni Karola Kurpińskiego Ty, któryśs stowa. Preludia nr 22 oraz a-moll doczekały się wznowienia w zbiorze Rączkowskiego i Gołosa $Z$ polskiej muzyki organowej XIX i XX wieku.

Wspomniany już zbiór Gołosa Mato znane polskie utwory organowe XIX/XX wieku wydany został w dwóch częściach. Część II z roku 1990 zawiera łącznie 18 kompozycji organowych. Na szczególną uwagę zasługują: chorał Allein Gott Augusta Freyera, Wesoty dzień dziś nam nastat Stanisława Moniuszki, Fuga op. 140 nt. Ojcze z niebios Stanisława Moniuszki, Prelude pour orgue Jana Maklakiewicza (1899-1954) oraz Preludium I i Preludium II Tomasza Ogiermana-Mańskiego (1889-1983) ${ }^{41}$.

Część pierwsza z roku 1989 zawiera wybór 22 mniej znanych przykładów polskiej muzyki organowej końca XIX i początku XX wieku. Z zawartych tam ciekawszych utworów wymienić należy: fantazję na organy Wawel Aleksandra Namysłowskiego (1853-1913) dedykowaną Feliksowi Nowowiejskiemu, preludium nt. pieśni Skoro ze snu wstaję z rana op. 26 Juliana Sztarki (1885-1940), preludium nt. kolędy W żtobie leży Szczepana Sieji (1883-1949), preludium nt.

37 J. Erdman, Organy, dz. cyt., s. 113.

${ }^{38}$ Zob. Wykaz materiatów nutowych, [w:] J. Gołos, Polskie organy i muzyka organowa, dz. cyt., s. 386.

39 Zob. T. Przybylski, Polska pieśn kościelna w twórczości organowej kompozytorów od XVI wieku do Mieczystawa Surzyńskiego, dz. cyt., s. 141.

${ }^{40} Z$ polskiej muzyki organowej XIX/XX wieku, dz. cyt., s. 91.

${ }^{41}$ Było dwóch braci Ogiermanów-Mańskich: Tomasz Ogierman-Mański był bratem Idziego. Zob. J. Drewniak, Kaptan - kompozytor. Dualizm powotania i twórczości ks. Idziego Ogiermana-Mańskiego (1900-1966), Warszawa 2007, s. 28. 
pieśni Krzyżu święty Eugeniusza Walkiewicza (1880-1946) i utwory Wincentego Rychlinga.

Postać Wincentego Rychlinga (1841-1896), Czecha z pochodzenia ${ }^{42}$, warta jest przypomnienia $\mathrm{z}$ dwóch powodów. Po pierwsze - muzyk ten piastował posadę organisty w królewskiej katedrze na Wawelu. Pisze o tym Tadeusz Przybylski:

Śp. Wincenty Rychling, prof. krakowskiego konserwatorium i organista katedralny na Wawelu, należał do szeregu wybitnych kompozytorów i pedagogów muzyki kościelnej. Pod jego okiem wykształciło się kilkuset organistów, będących obecnie przodownikami w tym zawodzie. Nie szczędził on swej pracy i dążył zawsze, aby uczący się pod nim mógł osiągnąć wykształcenie godne sztuki wykonywanej w Świątyniach Pańskich. Pracą swą podniósł wysoko muzykę w Krakowie, sam zaś po 15-letniej działalności nauczycielskiej zmarł jako ofiara tego zawodu, w niedostatku, w Krakowie w roku 1893, pozostawiając po sobie pamięć organisty i pedagoga w całem tego słowa znaczeniu ${ }^{43}$.

Drugim powodem zwrócenia uwagi na postać Wincentego Rychlinga jest fakt, że był on autorem znanych Pastoratek, zebranych i wydanych w roku 1953 przez Stanisława Niepielskiego (1865-1927) ${ }^{44}$. W zbiorze tym obok kompozycji Rychlinga znajdują się m.in.: Pastoratki autorstwa Niepielskiego (nr 27 i 77) oraz jedna kompozycja Walentego Deca (1857-1938) oznaczona w zbiorze numerem 66. Ten ostatni nawiązuje, podobnie jak jego nauczyciel ${ }^{45}$ - Rychling - do tradycji praktyki organistowskiej katedry wawelskiej. Inny zachowany zbiór Wincentego Rychlinga zawiera 11 zadań z harmonii (preludiów). W przedmowie do wydania tego zbioru napisano:

Preludia niniejsze pisał śp. W. Rychling dla swych uczniów w szkole na tablicy, które każdy z nich odpisywał w zeszycie. Podpisane wydawnictwo zebrało te szczątki i wydaje je drukiem, chcąc w ten sposób uczcić zasłużoną pracę śp. W. Rychlinga. Wydawnictwo „Muzyka i Śpiew”46.

42 Zob. T. Przybylski, Organistyka krakowska XVIII i XIX wieku i w latach międzywojennych XX wieku, dz. cyt., s. 51.

${ }^{43}$ W. Rychling, Zbiór Preludyj kościelnych na organ lub harmonium, z. 1, Kraków 1920.

${ }^{44}$ S. Niepielski (1865-1927) - dyrektor chóru przy kościele N.P. Marji w Krakowie.

45 Zob. T. Przybylski, Organistyka krakowska XVIII i XIX wieku i w latach międzywojennych XX wieku, dz. cyt., s. 51.

46 W. Rychling, Zbiór Preludyj kościelnych na organ lub harmonium, z. 1. 
Charakteryzując Pastorałki Rychlinga, Jerzy Gołos stwierdza: „Pod względem technicznym i harmonicznym większe Pastoratki Rychlinga przewyższają najlepsze utwory Moniuszki” ${ }^{47}$.

O znaczeniu twórczości organowej ks. Antoniego Chlondowskiego Tadeusz Przybylski pisze:

Twórczość organowa w latach międzywojennych była dość nikła, i to zarówno koncertowa, jak i użytkowa na potrzeby praktyki organistowskiej. Stąd odczuwało się ogromny brak literatury organowej na potrzeby liturgii. Biorąc pod uwagę ten fakt, jak i możliwości wykonawcze przeciętnego organisty, podjął się ks. A. Hlond ${ }^{48}$ wypełnić tę lukę skomponowaniem stosownych utworów przeznaczonych na potrzeby kościelne ${ }^{49}$.

Podstawowym dziełem ks. Antoniego Chlondowskiego jest Zbiór 225 tatwych preludiów na organy lub harmonium $w$ najczęściej używanych tonacjach dur i moll, który ukazał się w roku 1960. Badaczka twórczości tej postaci-Maria Wacholc - zwraca uwagę na to, że „praktyka komponowania utworów nadających się do wykonania albo na organach, albo na fisharmonii była powszechna w XIX i na początku XX wieku, szczególnie w kręgach muzyki kościelnej" ${ }^{50}$. Wiązało się to zapewne z brakiem organów we wszystkich kościołach, które to zastępowano często fisharmoniami ${ }^{51}$. We wstępie do tego zbioru wydanego nakładem Księgarni św. Wojciecha (Poznań-Warszawa-Lublin) czytamy:

W życiu muzycznym Kościoła katolickiego w Polsce znana jest postać księdza Antoniego Chlondowskiego, salezjanina. Biograf, który zajmie się kiedyś życiorysem tego kapłana-muzyka, wyliczy z pewnością obszernie jego kompozycje, większe i mniejsze utwory muzyczne i poda najważniejszą chyba datę z życia księdza Chlondowskiego, datę założenia przez niego Salezjańskiej Szkoły Muzycznej w Przemyślu i objęcia przez niego

47 J. Gołos, Polskie organy i muzya organowa, dz. cyt., s. 192; cytuję za: T. Przybylski, Organistyka krakowska XVIII i XIX wieku i w latach międzywojennych XX wieku, dz. cyt., s. 50-51.

${ }^{48}$ Kompozytor występuje także pod pseudonimem Chlondowski. Zob. Hlond, Antoni, [w:] Encyklopedia muzyczna PWM, t. 4 H-J, red. E. Dziębowska, Kraków 1993, s. 245.

${ }^{49}$ T. Przybylski, Ksiądz Antoni Hlond (Antoni Chlondowski) (1884-1963) - kompozytor polskiej muzyki organowej i religijnej w I potowie XX wieku, [w:] Zeszyty naukowe Akademii Muzycznej im. Stanistawa Moniuszki w Gdańsku, XXV, Gdańsk 1986, s. 180.

${ }^{50}$ M. Wacholc, Twórczość organowa ks. Antoniego Chlondowskiego, [w:] Zeszyty naukowe Akademii Muzycznej im. Stanistawa Moniuszki w Gdańsku, XXIX-XXX, Gdańsk 1991, s. 114.

${ }^{51}$ www.pl.wikipedia.org/wiki/Fisharmonia (20.01.2012). 
kierownictwa tej ważnej w życiu Kościoła w Polsce placówki. Biograf będzie więc musiał uwzględnić rolę ks. Chlondowskiego jako społecznika i wychowawcy licznych pokoleń organistowskich. Ta właśnie troska o dobre powołania organistowskie najwięcej zaprzątała i jeszcze dziś zaprząta jego umysł i serce. Z dala od wielkich kiedyś obowiązków na swojej obecnej placówce Pęcherskiej (koło Piaseczna) postanowił zebrać porzucone przez wojnę rękopisy nut, by - za zachętą swoich współbraci - wydać zbiór preludiów organowych, tak bardzo potrzebny naszym organistom ${ }^{52}$.

Warto też przytoczyć tekst przedmowy samego kompozytora, zachowany w rękopisie, który zdaniem ks. Tadeusza Przybylskiego mógł zostać zastąpiony cytowanym powyżej słowem arcybiskupa Baraniaka ${ }^{53}$ :

Niniejsze Preludia przeznaczone są raczej dla mniej zaawansowanych organistów, dlatego utrzymane są w starej harmonii cecyliańskiej, przejrzystej formie, niewyszukanym kontrapunkcie, łatwym układzie. Po każdej tonacji dur następuje tonacja moll, jako najbliżej z nią spokrewniona, by można przeplatać. Mylny jest sąd, że preludia molowe nadają się tylko na nabożeństwa żałobne ${ }^{54}$.

Zbiór ten składa się z 3 części, z których każda zawiera 75 preludiów: 15 utworów przypada na każdą tonację durową, a 10 - na molową. Utwory te posiadają podwójną numerację (w ramach danej części i całego zbioru), występują w tonacjach do czterech znaków przykluczowych (bemolowych i krzyżykowych) i zapisane są na dwóch pięcioliniach (głos najniższy wykonuje się wg oznaczeń - na manuale lub pedale). Preludia są przeważnie kilkunastotaktowe, w różnym metrum $(2 / 4,3 / 4,4 / 4,3 / 8,6 / 8)$, posiadają oznaczenia tempa oraz proponowaną dynamikę. Część pierwsza zawiera: 15 preludiów w tonacji C-dur, 10 preludiów w tonacji a-moll, 15 preludiów w tonacji G-dur, 10 preludiów w tonacji e-moll, 15 preludiów w tonacji D-dur, 10 preludiów w tonacji h-moll. W części drugiej występuje: 15 preludiów w tonacji A-dur, 10 preludiów w tonacji fis-moll,

52 Stowo wstępne ks. arcybiskupa A. Baraniaka, Poznańskiego Metropolity, [w:] A. Chlondowski, Zbiór 225 tatwych preludiów na organy lub harmonium w najwięcej używanych tonacjach dur i moll, Poznań, 1960, s. [1].

53 Zob. T. Przybylski, Ksiadz Antoni Hlond (Antoni Chlondowski) (1884-1963)..., dz. cyt. oraz tom XIII, s. 156.

${ }^{44}$ Zob. T. Przybylski, Ksiadz Antoni Hlond (Antoni Chlondowski) (1884-1963)..., dz. cyt., s. 180; oraz tom XIII, s. 156. 
15 preludiów w tonacji E-dur, 10 preludiów w tonacji cis-moll, 15 preludiów w tonacji F-dur, 10 preludiów w tonacji d-moll. Część trzecia obejmuje: 15 preludiów w tonacji B-dur, 10 preludiów w tonacji g-moll, 15 preludiów w tonacji Es-dur, 10 preludiów w tonacji c-moll, 15 preludiów w tonacji As-dur, 10 preludiów w tonacji f-moll. Utwory te nie nawiązują bezpośrednio do znanych melodii pieśni kościelnych.

Kompozytor bowiem uważał, że liturgiczne kompozycje organowe, grywane podczas nabożeństw, winny być wprawdzie osnute na motywach śpiewanych pieśni, lecz z powodu braku wystarczającej ilości takich kompozycji wystarczy, gdy będą tylko spokrewnione z pieśniami lub zbliżone do nich swym charakterem ${ }^{55}$.

Po 32 latach od publikacji 225 tatwych preludiów... ukazało się kolejne wydanie utworów Chlondowskiego zawierające tym razem 31 preludiów ${ }^{56}$; wyboru pod względem artystycznym i pedagogicznym oraz przygotowania do druku dokonał Mieczysław Tuleja - wieloletni organista kościoła pw. Stanisława Kostki na Dębnikach w Krakowie, który także przygotował materiał do druku.

Twórczość organowa ks. Idziego Ogiermana-Mańskiego (1899-1966), kolejnego dyrektora Szkoły Salezjańskiej w Przemyślu ${ }^{57}$, uważanego przez Jana Węcowskiego za najwybitniejszego kompozytora współczesnej użytkowej muzyki religijnej ${ }^{58}$, reprezentowana jest przez zbiór pt. Preludia na organy. Pozycja ta zawiera pięć z sześciu ${ }^{59}$ zachowanych po II wojnie światowej jego preludiów, wydanych przez Wydawnictwo Hejnał w Płocku w roku 2002"60. Autorowi niniejszego artykułu udało się dotrzeć do innego wydania (na powielaczu) jednego z preludiów (nr 5 w tonacji As-dur), w którym znalazła się następująca uwaga: „Preludia, $\mathrm{z}$ założenia utwory manuałowe, nie wymagają użycia pedału, jednak w miejscach

55 T. Przybylski, Ksiądz Antoni Hlond (Antoni Chlondowski) (1884-1963), dz. cyt., s. 183; oraz A. Chlondowski, Wstęp do antologii polskiej muzyki organowej XIX i XX wieku, Archiwum Towarzystwa Salezjańskiego, Czerwińsk n/Wisłą, rkps.

${ }^{56}$ Zob. A. Chlondowski, Preludia na organy, Kraków 1992, s. 5.

57 Zob. T. Przybylski, Szkota organistowska w Przemyślu w latach 1916-1963 na tle ogólnego procesu ksztatcenia organistów w Polsce, [w:] W 50. rocznicę ogtoszenia encykliki papieża Piusa XII Musicae sacrae disciplina, Kraków 2005, s. 152 (Pro Musica Sacra, 2).

58 I. Ogierman-Mański, Preludia na organy, Płock 2002. Słowo wstępne ks. Z. Malinowskiego.

59 Zob. J. Drewniak, Kaptan - kompozytor. Dualizm powotania i twórczości ks. Idziego Ogiermana-Mańskiego (1900-1966), dz. cyt., s. 159.

${ }^{60}$ Zob. J. Drewniak, Kaptan - kompozytor. Dualizm powotania i twórczości ks. Idziego Ogiermana-Mańskiego (1900-1966), dz. cyt., s. 276. 
wymagających dużej rozpiętości ręki, pedał może być pomocny”. Zapewne uwaga ta dotyczyła nie tylko tego jednego utworu, ale także innych kompozycji Mańskiego. Zapewne także z tego samego powodu (zbyt dużej rozpiętości głosów) wydawca płocki zamieścił w takcie 21 preludium nr 4 na temat Jezus malusieńki ${ }^{61}$ uwagę „Ped. (ad lib.)”.

Do twórczości wybitnie użytkowej zaliczyć należy także Eatwe $i$ krótkie preludia na harmonium osnute na tematach nabożnych pieśni ks. Leona Świerczka ze Zgromadzenia Księży Misjonarzy. Zbiór ten zawiera 18 króciutkich kompozycji wydanych nakładem Księgarni Stefana Kamińskiego w Krakowie. W uwadze redaktorskiej czytamy, że niektóre z nich mogą być przygrywkami do pieśni, jeżeli tonacja pieśni jest odpowiednia, w przeciwnym razie należy pieśń lub preludium odpowiednio przetransponować. Ze Zgromadzenia Księży Misjonarzy wywodzi się także ks. Hieronim Feicht ${ }^{62}$, który skomponował 5 łatwych triów na tematy pieśni kościelnych oraz trzy przegrywki (interludia) do pieśni adwentowej $M a-$ drości wieczna (1937).

Najciekawszym, a zarazem najbardziej obszernym zbiorem utworów organowych okresu powojennego były Preludia na organy bez pedatu, wydane przez Instytut Wydawniczy PAX w Warszawie w roku 1960, a zebrane i opracowane przez Feliksa Rączkowskiego - wieloletniego organistę kościoła św. Krzyża w Warszawie. W zbiorze tym znajduje się 131 kompozycji różnych autorów, które oparte są na melodiach pieśni kościelnych, chorale gregoriańskim, są tam także i takie, które choć utrzymane w podobnej stylistyce kościelnej, nie nawiązują jednak do żadnych znanych melodii. Kompozytorami, których utwory pojawiają się w zbiorze najczęściej, są Józef Furmanik i Feliks Rączkowski. Ponadto wymienić należy: Zdzisława Nowackiego ${ }^{63}$, Tadeusza Jarzęckiego, Stefana Wrocławskiego ${ }^{64}$, Fran-

${ }^{61}$ Melodia tej kolędy posłużyła także Zygmuntowi Rychertowi (ur. 1947), założycielowi i dyrektorowi artystycznemu Filharmonii Bałtyckiej w Gdańsku, do skomponowania preludium chorałowego pt. Lulajże Jezuniu. Utwór ten wydany został przez Wydawnictwo Organon Macieja Babnisa z Gdańska w roku 1998.

${ }^{62}$ Muzykolog, edytor dawnej muzyki polskiej.

${ }^{63}$ Autor ma wątpliwości dotyczące imienia Nowackiego. W zbiorze Rączkowskiego figuruje „Zdzisław Nowacki”, natomiast Jerzy Gołos w swojej książce Organy i muzyka organowa wymienia w wykazie materiałów nutowych „ks. Henryka Nowackiego” jako autora preludiów zamieszczonych przez Rączkowskiego. Mieczysław Tuleja posiada informacje z przekazu ustnego, że są to dwaj różni kompozytorzy. Jedno, co jest pewne - kompozycje Nowackiego zawierają elementy harmoniki jazzującej i są wyraźnie w opozycji do utworów inspirowanych cecyliańską odnową muzyki kościelnej.

${ }^{64} \mathrm{~W}$ środowisku radomskim rozpowszechnione jest 32 preludiów tego organisty, spośród których 6 umieścił Rączkowski w swoim zbiorze. Utwory te podzielone zostały na 3 części, 
ciszka Walczyńskiego, Henryka Makowskiego, Feliksa Nowowiejskiego, Tadeusza Paciorkiewicza oraz Mariana Sawę.

Preludia oparte na melodiach pieśni kościelnych ułożone zostały w kolejności roku kościelnego: $11 \mathrm{z}$ nich to preludia na Adwent, 15 na Boże Narodzenie, 11 na Wielki Post i 5 na Wielkanoc. Ponadto zamieszczone zostały kompozycje oparte na pieśniach eucharystycznych i przygodnych oraz o tematyce maryjnej. W zbiorze tym można także znaleźć: marsze ślubne (nr 93, 94) i żałobne (nr 95 i 96), preludia na Kyrie, Gloria, Credo, Ofertorium, Sanctus, Benedictus, Agnus Dei oraz preludia bez tytułów. W wydaniu tym znajduje się m.in.: preludium nr 60 Święty Boże Mieczysława Surzyńskiego, będące manuałową wersją szóstej wariacji jego Improwizacji... na temat tejże pieśni. Ostatnią pozycją zbioru preludiów jest wariacyjne opracowanie Bogurodzicy Feliksa Rączkowskiego. Jacek Basista w swojej pracy Feliks Rączkowski-wirtuoz, pedagog, kompozytor i animator życia muzycznego w dokumentach $i$ wspomnieniach wymienia kilka niewydanych jeszcze kompozycji Rączkowskiego (będących w posiadaniu córki kompozytora - Marzeny) przeznaczonych do wykonania na organach solo. Są to: Bogurodzica - improwizacja (1968), Ojcze z niebios - preludium, Preludium Andante, Preludium e-moll, Marsz żatobny na organy (1948), pastorałka na organy na temat kolędy Anielski chór, Twoja cześć chwata - preludium, Nie opuszczaj nas - chorał (1938), Rozmyślajmy dziś - chorał (1938), preludium na temat Boże $w$ dobroci i pastorałka na organy solo na temat kolędy Zygmunta Noskowskiego Witaj, Gwiazdko ztota ${ }^{65}$. Należy wspomnieć także o śpiewniku Feliksa Rączkowskiego Wielbij, duszo moja, Pana, wydanym przez Pax w Warszawie w roku 1956, który zawiera wybór akompaniamentów organowych do polskich pieśni kościelnych. Większość opracowanych pieśni zawiera także wstępy (przygrywki) oraz zakończenia. Stosunkowo niewielki dorobek utworów organowych o charakterze użytkowym Feliksa Rączkowskiego uzupełniają jeszcze 2 chorały ${ }^{66}$ : Ach mój Jezu (1945) (manuałowy) i Gorzkie żale skomponowane w roku 1939 (z partią pedałowa).

w pierwszej części znajdują się preludia oparte na pieśniach m.in. maryjnych i eucharystycznych (14); w drugiej są preludia na Adwent (3) i Boże Narodzenie (5), a w trzeciej zamieszczono kompozycje na Wielki Post (7) i Wielkanoc (3). Wszystkie te kompozycje utrzymane są w duchu cecyliańskim, melodia pieśni opracowana została w układzie 3 lub 4-głosowym.

${ }^{65} \mathrm{~J}$. Basista, Feliks Rączkowski - wirtuoz, pedagog, kompozytor i animator życia muzycznego, $w$ dokumentach $i$ wspomnieniach, Kraków 2010. Praca dyplomowa napisana pod kierunkiem dr. M. Stefańskiego, Akademia Muzyczna w Krakowie. Autor artykułu dziękuje panu Jackowi Basiście za udostępnienie swojej pracy.

${ }^{66}$ Copyright 1946 by Polskie Wydawnictwo Muzyczne Cracow. 
Osobę Józefa Furmanika (1867-1953) wspomina Tadeusz Przybylski:

Jedną z tych niesłusznie zapomnianych postaci, a bardzo zasłużonej dla rodzimej muzyki kościelnej jest niewątpliwie Józef Furmanik, żyjący na przełomie XIX i XX wieku, działający przez wiele lat w Warszawie jako organista, dyrygent chórów kościelnych, kompozytor, pedagog ${ }^{67}$. [...] Twórczość kompozytorska Józefa Furmanika składa się głównie z użytkowych utworów chóralnych i organowych, przeznaczonych głównie do wykonania w świątyniach ${ }^{68}$. [...] Stanowią one przykład nieskomplikowanej, lecz wysoce wartościowej literatury organowej, tworzący użytkowy repertuar organistowski tamtych czasów ${ }^{69}$.

Znaczna cześć kompozycji Furmanika zachowała się dzięki zapobiegliwości sióstr zakonnych ze Zgromadzenia Sióstr Franciszkanek od Cierpiących w Kozienicach, gdzie kompozytor spędził ostatnie chwile swego życia. Szczególne zasługi w propagowaniu twórczości Józefa Furmanika przypadły siostrze Barbarze Wycech, która zebrała i opracowała jego preludia w dwuczęściowym, ósmym zeszycie zbioru Tibi Domine ${ }^{70}$. W części I zbioru zamieszczone zostały 103 preludia na organy bez pedału (wyjątek stanowią preludia nr 93 i 103). Są to kompozycje użytkowe o różnym czasie trwania, najczęściej kilkunastotaktowe, stosunkowo łatwe i nieskomplikowane, nienawiązujące do tematów pieśni (z wyjątkiem preludium nr 87 - na temat pieśni Witam Cię, witam). W zeszycie znajduje się ponadto: 5 ćwiczeń na gamach (tonacjach) C, G, D, A i E oraz 17 dwugłosowych kanonów. Większość preludiów utrzymana jest w fakturze organowej, niemniej spotkać można także fakturę fortepianową (np. nr 95 i 96). Utwory te są w różnym metrum, w tonacjach durowych i molowych do 4 znaków przykluczowych. Niektóre z nich zostały zatytułowane: nr 91 - Improwizacja, nr $101-$ Marsz $\dot{z} a$ tobny, nr 102 - Sonatinka.

W części drugiej omawianego zeszytu 8 Tibi Domine znajdują się preludia oparte na pieśniach kościelnych przeznaczone na różne okresy roku kościelnego

${ }^{67}$ J. Furmanik, Preludia II na organy, Lublin 2010 s. 3. Przedmowa do wydania T. Przybylskiego.

68 T. Przybylski, Józef Furmanik (1867-1953) i jego muzyka organowa, [w:] Organy i muzyka organowa, XII, Gdańsk 2003., s. 309, (Prace Specjalne, 61).

${ }^{69}$ W. Pietrzak, Żcie i twórczość kompozytorska Józefa Furmanika, Warszawa 1979, s. 241-267. Cytuję za: T. Przybylski, Józef Furmanik (1867-1953) i jego muzyka organowa, [w:] Organy i muzyka organowa, XII, Gdańsk 2003, s. 313 (Prace Specjalne, 61).

${ }^{70}$ Wstęp, [w:] J. Furmanik, Tibi Domine. Preludia, z. 8, cz. 2, Lublin 2010. 
(Adwent -8 , Boże Narodzenie -13 , Wielki Post -10 , Wielkanoc - 6, pieśni różne - 16). Numeracja preludiów jest podwójna, jedna wynika z przyporządkowania do danego okresu, druga - z kolejności wszystkich preludiów w zeszycie. Nie wiadomo, dlaczego preludia części drugiej zaczynają się od nr 105 (w części pierwszej kończą się na numerze 103). Niektóre z omawianych kompozycji Furmanika znalazły się także we wcześniej omawianym zbiorze Feliksa Rączkowskiego Preludia na organy bez pedatu. Nazwane są tam (tylko) preludiami, choć występują niejednokrotnie w towarzystwie fugetty. Ponadto niektóre z nich zostały skrócone w porównaniu do wydania Tibi Domine (np. Archaniot Boży Gabriel, hejnał Wszyscy zaśpiewajmy, Chrystus zmartwychwstan jest) lub skrócone i przetransponowane do niższej tonacji (np. Zdrowaś bądź, Maryja). Kompozycje Furmanika doczekały się także współczesnej reedycji w postaci dwóch tomów Preludiów (I i II), wydanych przez wydawnictwo Polihymnia w Lublinie w roku 2010.

U schyłku wieku XX mimo dokonujących się przemian stylistycznych i zmieniających się oczekiwań w stosunku do muzyki kościelnej organy pozostają nadal wierne liturgii, a współczesna literatura organowa wzbogaca się o „nowe” utwory użytkowe, choć jak twierdzi Marta Szoka:

sytuacja współczesnego kompozytora jest szczególnie trudna i złożona, stoi on bowiem wobec alternatywy: historycyzm czy modernizm ${ }^{71}$. [...] Dodatkową komplikacją jest wielowiekowy związek organów z liturgią, który powoduje, że charakter estetyczny muzyki organowej jest ukształtowany przez jej funkcję liturgiczną ${ }^{72}$.

Tematami zaczerpniętymi z pieśni kościelnych interesowali się także kompozytorzy żyjący na przełomie XX i XXI wieku. Wśród nich dominował znany i ceniony w Polsce oraz poza granicami kraju improwizator i organista warszawski, uczeń Feliksa Rączkowskiego, Marian Sawa. Wśród niezliczonych jego kompozycji organowych znajdują się także te z gatunku twórczości użytkowej. Wydane zostały dotychczas dwa odrębne cykle preludiów organowych Sawy. Pierwszy z nich to Preludia organowe na temat polskich pieśni kościelnych opublikowany $\mathrm{w}$ roku 2004 w Krakowie przez wydawnictwo Zbigniewa Indyka. We wstępie do tego wydania czytamy m.in.:

${ }^{71}$ M. Szoka, Twórczość organowa Jerzego Bauera - próba charakterystyki, [w:] Organy i muzyka organowa, V, Gdańsk 1984, s. 269 (Prace Specjalne, 33).

${ }^{72}$ M. Szoka, Twórczość organowa Jerzego Bauera - próba charakterystyki, dz. cyt., s. 269. 
To kilkadziesiąt kompozycji o urozmaiconej fakturze, różnym stopniu trudności technicznych, ciekawej harmonii i oryginalnej formie. Wielką ich wartością jest to, iż kompozytor oparł swoje konstrukcje na melodiach tradycyjnych melodii kościelnych, znanych większości Polaków ${ }^{73}$.

Zbiór Sawy zawierają łącznie 65 kompozycji. Są to opracowania pieśni: na Adwent - 5, Boże Narodzenie - 10, Wielki Post - 10, Wielkanoc - 9, ku czci Najświętszego Sakramentu -11, do Najświętszego Serca Pana Jezusa - 10 oraz o Najświętszej Maryi Pannie - 10. Preludia organowe Sawy w pewnym sensie nawiązują do śpiewnika Wielbij duszo moja Pana Feliksa Rączkowskiego. Z założenia prawie każda melodia pieśni jest tam poprzedzona wstępem i zawiera kilkutaktowe zakończenie (wyjątek stanowią niektóre pieśni, jak np.: Zdrowaś bądź Maryja nr 5 i Ogrodzie Oliwny nr 20, w których brak jest wstępu). Kompozytor najczęściej prezentuje całą melodię pieśni w głosie najwyższym (np. Oto Pan Bóg przyjdzie nr 3) lub w innym głosie (np. Gtos wdzięczny z nieba wychodzi $\mathrm{nr}$ 2). Niekiedy repetuje melodię pieśni (jako kolejną zwrotkę) w innej tonacji (np. Gtos wdzięczny z nieba wychodzi nr 2 - pierwsza zwrotka w tonacji D-dur, druga w E-dur), wyodrębnia także melodię pieśni na oddzielnym manuale (np. Krzyżu Chrystusa bądżże, pochwalony nr 17), a czasami melodia pieśni przechodzi na moment z klucza wiolinowego do basowego (np. w Krzyżu Chrystusa, bądżze pochwalony nr 17). Ponadto stosuje imitację (np. Któryś za nas cierpiat rany nr 19, Ty, któryś gorzko na krzyżu umierat nr 24 lub Pan zstąpit z nieba nr 42). Zdarza się też, że oryginalna melodia w dalszym przebiegu zostaje ozdobiona (np. w Rozmyślajmy dziś, wierni chrześcijanie nr 23) lub opracowana wariacyjnie (np. w Alleluja! Jezus żyje nr 26). Marian Sawa stosuje także fakturę fortepianową (Wesoty nam dziś dzień nastat nr 29), a w preludium Zwycięzca śmierci i szatana $\mathrm{nr} 33$ zmienia tonację melodii pieśni, zaczynając od A-dur i poprzez Bdur, kończąc w H-dur. W opracowaniu pieśni nr 38 Ktaniam się Tobie zakończenie pieśni jest menuetem. Ciekawym opracowaniem pieśni jest Bogurodzica, Dziewica nr 57, wykorzystująca temat najstarszej polskiej pieśni kościelnej.

Kolejnym wyborem utworów użytkowych Mariana Sawy są Polskie preludia organowe na Adwent i Boże Narodzenie, wydane przez Warsaw Music Edition w roku 2006. W przedmowie do tego zbioru napisano:

Urozmaicona faktura preludiów na temat polskich pieśni adwentowych i kolęd, które trzymacie Państwo w swoich rękach, ich różnorodność

${ }^{73}$ M. Kruzel-Sosnowska, Przedmowa, [w:] M. Sawa, Preludia organowe na temat polskich pieśni kościelnych, Kraków 2004, s. [6] 
formy, prostota i piękno oryginalnej harmonii, a także interesująca rytmika sprawiają, iż słucha się ich z wielkim zainteresowaniem ${ }^{74}$.

Preludia te - opracowania pieśni adwentowych (5) oraz bożonarodzeniowych (6) - odznaczają się przejrzystością faktury, są proste, a zarazem zwracają uwagę interesującym dysonansowym brzmieniem. Kompozytor często wprowadza imitacje motywów pieśni oraz elementy fugowane, np. w kolędzie Aniot pasterzom mówit po wariacyjnym opracowaniu pieśni następuje fuga.

$\mathrm{Na}$ uwagę zasługuje również twórczość Eugeniusza Brańki, wieloletniego organisty klasztoru na Jasnej Górze w Częstochowie. Większość jego utworów organowych, a w szczególności wariacji, inspirowana była praktyką improwizacji, którą kompozytor sam często wykorzystywał podczas nabożeństw. Improwizowanie przez niego krótkich preludiów, interludiów i postludiów wypełniało czas oczekiwania przez wiernych na liturgię, a stosowanie ich podczas mszy wzmagało jej mistyczno-kontemplacyjny charakter. Z czasem kompozytor zaczął zapisywać swoje improwizacje, nadając im tym samym ostateczną, zamkniętą formę: tematu $\mathrm{z}$ wariacjami, fantazji czy preludium na dany temat. W utworach tych wykorzystywał klasyczne środki techniki wariacyjnej, takie jak zmiana trybu, faktury, praca motywiczna, figuracja, polifoniczne przekształcenia, ukazywanie tematu w różnych głosach czy wprowadzenie figur zdobniczych. Sam Brańka charakteryzował swoje utwory jako polifonizujące, fantazyjne i eklektyczne ${ }^{75}$.

Preludia na temat pieśni kościelnych Tadeusza Machla to wybrane opracowania 45 pieśni na cały rok liturgiczny, zharmonizowane i poprzedzone wstępem organowym.

Kompozycje te o różnym stopniu trudności mogą pełnić wieloraką, użytkową funkcję - zarówno liturgiczną, jak i pedagogiczną oraz koncertową. Ponadto organiści mniej wprawni technicznie będą mogli korzystać z samych harmonizacji pieśni kościelnych, które ze względu na niższy stopień trudności są dostępne większej rzeszy wykonawców ${ }^{76}$.

W zbiorze tym znajdują się: 3 pieśni na Adwent, 5 pieśni na Boże Narodzenie, 6 pieśni na Wielki Post, 4 pieśni na Wielkanoc, 1 pieśń na Wniebowstąpienie, 5 pieśni ku czci Najświętszego Sakramentu, 3 pieśni ku czci Najświętszego Serca

${ }^{74}$ M. Kruzel-Sosnowska, Przedmowa, dz. cyt., s. [6].

${ }^{75} \mathrm{Na}$ podstawie informacji uzyskanych od syna organisty - Karola Brańki - na temat twórczości jego ojca.

76 T. Machl, Stowo od autora, [w:] T. Machl, Preludia na temat pieśni kościelnych, Kraków 1998, s. [4]. 
Pana Jezusa, 9 pieśni ku czci Najświętszej Maryi Panny, 5 pieśni przygodnych, suplikacje oraz 3 hymny. Przy każdym utworze kompozytor umieszcza propozycję rejestracyjną. Na końcu każdego opracowania podany jest tekst pieśni. Przewidziane przez kompozytora wstępy do pieśni wymagają od grającego solidnego przygotowania ze względu na ich duży stopień trudności. W zamieszczonej nocie redakcyjnej czytamy:

Bogactwo pomysłów muzycznych prof. Tadeusza Machla znane z Jego wcześniejszych kompozycji znalazło poprzez te opracowania kolejną, wspaniałą artystyczną realizację. To bogactwo powoduje duże zróżnicowanie - część przygrywek wymaga od wykonawcy znacznego zaawansowania technicznego, inne natomiast mniejszego. Natomiast język, jakim Autor się posługuje, właściwy jest tylko Jemu ${ }^{77}$.

Indywidualny jezzyk muzyczny, charakterystyczny bardziej dla Machla kompozytora współczesnego niż Machla organisty-praktyka, a także skomplikowana faktura jego utworów i nasycona dysonansami harmonia sprawiają, że choć „opisywany zbiór przedstawia ogromną wartość poznawczą i dydaktyczną, a nade wszystko stanowi świadectwo twórczego podejścia do organów i muzyki organowej" ${ }^{\prime 7}$, to jednak nadaje się chyba w mniejszym stopniu do użycia w praktyce liturgicznej.

Jan Janca (ur. w 1933 rok) jest autorem m.in. krótkich preludiów organowych, napisanych z myślą o wykorzystaniu ich zarówno w praktyce liturgicznej, jak i koncertowej. „Estetyka Jana Jancy polega raczej na możliwości pogodzenia komponowania użytkowego z najwyższymi wymaganiami kompozytorskimi”79. Wybrane jego utwory o charakterze użytkowym zatytułowane Ausgewaelte Choralvorspiele, wydane zostały przez Strube Verlag (2005 rok) w dwóch zeszytach. Pierwszy z nich zawiera 11 kompozycji na Adwent i Boże Narodzenie (skomponowanych w latach 1975-1985), drugi natomiast zamieszcza 16 utworów na Wielki Post i Wielkanoc (1975-2005). Przygrywki chorałowe Jancy opatrzone zostały tytułami w języku niemieckim, stanowią bowiem opracowania melodii zaczerpniętych z tradycji Kościoła niemieckiego. Na szczególną uwagę zasługują: 1) adwentowa toccatina. Jauchzet, ihr Himmel (Lobe den Herren) (zeszyt $1 \mathrm{nr} 7$ ). Materiał melodyczny chorału użytego w tym utworze znany jest w polskim Ko-

77 Z. Indyk, Wstęp, [w:] T. Machl, Preludia na temat pieśni kościelnych, dz. cyt., s. [4].

78 W. Delimat, niepublikowany wywiad w dniu 1 IX 2011 (zbiory prywatne Autora).

${ }^{79}$ M. Heinemann, Do liturgii i na koncert: Orgelverse Jana Jancy. Na siedemdziesiąte urodziny kompozytora, tłum. M. Szoka, „Ruch Muzyczny” 19 (2003), s. 14. 
ściele katolickim jako melodia pieśni Gtoś imię Pana. 2) toccatina Christ ist erstanden (zeszyt $2 \mathrm{nr} 8$ ) wykorzystuje natomiast melodię pieśni wielkanocnej Chrystus zmartwychwstan jest. Jan Janca jest także autorem wersetów organowych Orgelverse: Hilf, Herr meines Lebens; Gott liebt diese Welt, Solang es Menschen gibt auf Erden, Brich dem Hungrigen dein Brot, toccat chorałowych: Wachet auf, ruft uns die Stimme i Nun danket all und bringet Ehr, medytacji na okres Adwentu Maria durch ein Dornwald ging oraz toccatiny Hört, der Engel helle Lieder. Marta Szoka w recenzji płyty ${ }^{80}$ nagranej przez Ludgera Lohmana z utworami Jancy zauważa, że płyta ta (czytaj: twórczość Jancy)

dla wszelkiej maści reformatorów, dążących do liberalizacji w dziedzinie muzyki kościelnej, może być dowodem, że nowy język i ekspresja dadzą się pogodzić z formami i technikami odziedziczonymi po epoce baroku, złotej epoce muzyki organowej, że nowoczesność muzycznej oprawy liturgicznej nie polega na naśladowaniu stylu królującego na listach przebojów ${ }^{81}$.

Ze względu na swój specyficzny charakter i nie zawsze najwyższą rangę artystyczną użytkowa muzyka organowa ma zapewne tylu zwolenników, co przeciwników. Na pewno będzie ona przydatna przede wszystkim dla muzyków kościelnych mniej zaawansowanych w grze na organach i sztuce improwizacji, którzy poszukują wsparcia w postaci krótkich, nieskomplikowanych utworów mających zastosowanie w posoborowej liturgii Kościoła rzymskokatolickiego. Współcześni organiści powinni być tego świadomi, że „dziś nie da się zaakceptować wykonywania w liturgii jakiejkolwiek kompozycji. Stosunkowo najłatwiej można dobrać utwory oparte na chorale gregoriańskim lub pieśniach kościelnych"82. Nie można oczekiwać, że każdy organista kościelny będzie potrafił improwizować czy wykonywać odpowiednie utwory na odpowiednim poziomie, bowiem, jak zaznacza papież Franciszek, „może tylko improwizować dobrze ten, kto ma wyjątkowe dary i bardzo solidne przygotowanie techniczne. (...) Wiele improwizacji powoduje, że włosy się jeżą na głowie" ${ }^{83}$. Dlatego też dostępna muzyka użytkowa będzie w wielu wypadkach dobrze spełniać swoje

${ }^{80}$ Ludger Lohmann na organach kościoła św. Jana w Tübingen, Musikproduction Dabringhaus und Grimm, 606 1104-2 (2002).

${ }^{81}$ M. Szoka, Jan Janca. Organ Works, „Ruch Muzyczny” 21 (2002), s. 38.

${ }^{82}$ I. Pawlak, Muzyka liturgiczna po Soborze Watykańskim II w świetle dokumentów kościota, Lublin 2001, s. 271.

${ }^{83}$ Czego oczekuję, fragment wypowiedzi Papieża Franciszka do organistów z dn. 13 stycznia 2014 r., tłumaczenie z języka włoskiego: Wojciech Szychowski. 
zadanie, bowiem lepiej jest, także z punktu widzenia liturgii, wykonać utwór mniej skomplikowany dobrze, niż trudny źle. Warto jednak pamiętać o tym, że dzisiejsza liturgia, zwłaszcza sprawowana w niedzielę lub inny dzień świąteczny, nie powinna całkowicie ograniczać się tylko i wyłącznie do śpiewu wiernych oraz muzyki użytkowej. Czytamy na ten temat w posoborowych dokumentach Kościoła:

Nie zaprzeczamy wartościom pieśni ludowych ani nie odrzucamy całkowicie „muzyki użytkowej”, ale sprzeciwiamy się wyłączności („tylko ta muzyka"), która nie jest usprawiedliwiona ani postanowieniami soboru, ani koniecznością duszpasterską ${ }^{84}$.

Liturgia świąteczna potrzebuje ozdobnej szaty muzycznej, dlatego zrodziła się potrzeba włączenia do niej ambitniejszej twórczości organowej. Polska religijna muzyka organowa o charakterze koncertowym może być jej ważnym filarem, ale tym problemem zajmiemy się przy następnej okazji.

\section{Streszczenie}

Polska twórczość organowa zainspirowana pieśnią kościelną w liturgii Kościoła rzymskokatolickiego

Znajomość literatury organowej rodzimych kompozytorów nadal pozostawia wiele do życzenia. Współcześni organiści kościelni, jeśli już wykonują solową muzykę organową w liturgii, sięgają często po utwory wielkich mistrzów europejskich, zapominając o polskim skarbcu muzyki religijnej. Trafnym spostrzeżeniem ujmującym istotę stanu wiedzy większości młodych (i nie tylko młodych) organistów na temat polskiej muzyki organowej wydaje się znane powiedzenie „cudze chwalicie, swego nie znacie...”.

Dlaczego polska religijna literatura organowa jest tak ważna dla współczesnego muzyka kościelnego? Z pewnością dlatego, że w liturgii Kościoła rzymskokatolickiego

${ }^{84}$ Raport o stanie wiary. $Z$ ks. Kardynatem Josephem Ratzingerem rozmawia Vittorio Messori, przekł. Z. Oryszyna, weryf. i uzup. przekł. J. Chrapek, red. J. Klecel, Marki 1986, s. 110nn, cytuję za: I. Pawlak, Muzyka liturgiczna po Soborze Watykańskim II w świetle dokumentów Kościota, Lublin 2001, s. 75. 
„bardzo pożądane będą (czytaj: są, przyp. W. Z.) kompozycje oparte na motywach pieśni kościelnych" ${ }^{25}$.

Pieśń kościelna już od XVI wieku wykorzystywana była przez kompozytorów polskich jako materiał melodyczny komponowanych przez nich utworów organowych. Pierwsze z takich kompozycji powstawały poprzez adaptację utworów wokalnych na instrument klawiszowy. Należy tu wymienić m.in.: XVI-wieczne zabytki muzyki polskiej - Tabulaturę Jana $z$ Lublina z roku 1540, Tabulaturę klasztoru Św. Ducha z roku 1548 oraz Tabulature Warszawskiego Towarzystwa Muzycznego z ok. 1580 roku. Pod koniec wieku XVIII i w wieku XIX zauważalne staje się w Europie, a także w Polsce, zeświecczenie muzyki organowej spowodowane m.in. wpływem szkoły neapolitańskiej. Elementy świeckie i operowe przenikają także do muzyki kościelnej o charakterze użytkowym.

Warto pamiętać, że polska twórczość religijna to dorobek wybitnych polskich organistów-wirtuozów, nierzadko świetnych improwizatorów, posiadających wieloletnią praktykę zawodową. Twórcami tej literatury byli w pierwszym rzędzie działający na wielu płaszczyznach muzycznych organiści kościelni, kompozytorzy, organizatorzy życia muzycznego i profesorowie wyższych uczelni. Do tego kręgu postaci zaliczyć należy: Władysława Żeleńskiego, Stefana Surzyńskiego, Mieczysława Surzyńskiego, Feliksa Nowowiejskiego, Walentego Deca, Wincentego Rychlinga, Kazimierza Garbusińskiego, Feliksa Rączkowskiego, Józefa Furmanika oraz duchownych: ks. Gustawa Roguskiego, ks. Józefa Surzyńskiego, ks. Franciszka Walczyńskiego, ks. Antoniego Chlondowskiego czy ks. Idziego Ogiermana Mańskiego. W tym duchu tworzyli także organiści naszych czasów jak Marian Sawa, Tadeusz Machl czy Jan Janca.

Autor niniejszej publikacji podejmuje się prezentacji polskiej twórczości organowej możliwej do zastosowania w liturgii Kościoła rzymskokatolickiego. Dokonując podziału na muzykę użytkową (stanowi ona pierwszą część całego artykułu) i koncertową, ma jednak świadomość, że

nie można przeprowadzić całkiem ściśle podziału na muzykę użytkową (dydaktyczną i kościelna) oraz koncertową, ponieważ wśród utworów użytkowych spotykamy większe formy o dużych ambicjach artystycznych, grywane zarówno w kościele, jak i na sali koncertowej ${ }^{86}$.

Ze względu na swój specyficzny charakter i nie zawsze najwyższą rangę artystyczną użytkowa muzyka organowa ma zapewne tylu zwolenników, co przeciwników. Na pewno będzie ona przydatna przede wszystkim dla muzyków kościelnych mniej zaawansowanych w grze na organach i sztuce improwizacji, którzy poszukują wsparcia w postaci krótkich,

${ }^{85}$ A. Zając, Wybrane aspekty postugi organisty w spoteczności parafialnej, dz. cyt., s. 81.

${ }^{86} \mathrm{~J}$. Gołos, Polskie organy i muzyka organowa, dz. cyt., s. 203. 
nieskomplikowanych utworów mających zastosowanie w posoborowej liturgii Kościoła rzymskokatolickiego.

\section{Summary}

Polish organ music inspired by church songs in the Catholic liturgy, part I

The knowledge of organ literature devoted to native composers leaves much to be desired. If they even perform solo organ music at liturgy, contemporary church organists often reach for the works of grand European masters, forgetting about the Polish reservoir of sacral pieces. An old proverb "the grass is greener on the other side of the fence" is an accurate description of the state of knowledge of young (and the older) organists on Polish organ music.

Why is therefore Polish sacral organ literature so important for the contemporary church musician? Most importantly because, in the Roman Catholic church liturgy, "compositions based on church songs shall (i.e. are) desirable".

As early as in the $16^{\text {th }}$ century, church song was used by the Polish composers as the melodic material for the organ pieces they composed. The first church compositions were created through adapting vocal pieces to the purposes of key music. Some of the most prominent examples include e.g. $16^{\text {th }}$-century Polish music monuments - John of Lublin Tabulator of 1540, The Saint Ghost Monastery Tabulator of 1548 and the Warsaw Music Society Tabulator from approx. 1580. The turn of the $18^{\text {th }}$ and the $19^{\text {th }}$ century in Europe and in Poland displays a secularization of organ music, influenced by the spread of the Naples school. Secular and opera elements influence church music, which gradually develops utilitarian properties.

It is worth to remember that the Polish religious oeuvre is the contribution of Polish organists-virtuosos, often great improvisers, with extensive professional practice. The first creators of this literature were church organists, active on many a musical platform, composers, organizers of music life and university professors. This family of authors includes: Władysław Żeleński, Stefan Surzyński, Mieczysław Surzyński, Feliks Nowowiejski, Walenty Dec, Wincenty Rychling, Kazimierz Garbusiński, Feliks Rączkowski, Józef Furmanik, as well as the following priests: Gustaw Roguski, Józef Surzyński, Franciszek Walczyński, Antoni Chlondowski, or Idzi Ogierman-Mański. Also contemporary organists, such as Marian Sawa, Tadeusz Machl, or Jan Janca have been composing in this spirit.

The author of this publication attempts at presenting the Polish organ music oeuvre, to be applied in the Roman Catholic church liturgy. Performing a division into applied music (as presented in the $1^{\text {st }}$ part of the article) and concert music, the artist is aware that "we cannot make a precise classification into applied music (both didactic 
and church music) and concert music, since applied pieces contain numerous elaborate forms with grand artistic ambitions, played both in church and in the concert room"2.

Due to the specific character and sometimes not the top-notch artistic rank, organ music surely has as many advocates as it has opponents. Most of all, it will surely be found useful by church musicians who are less advanced in organ play and the art of improvisation, who seek support in the form of short, non-complex pieces applied in the postcouncil Roman Catholic liturgy.

Stowa kluczowe muzyka polska, muzyka organowa, muzyka w liturgii, preludia organowe, muzyka liturgiczna

Keywords music, organ music, music in the liturgy, organ preludes, liturgical music

\section{Bibliografia}

Basista J., Feliks Rączkowski - wirtuoz, pedagog, kompozytor i animator życia muzycznego, $w$ dokumentach i wspomnieniach, Kraków 2010. Praca dyplomowa napisana pod kierunkiem dr. M. Stefańskiego, Akademia Muzyczna w Krakowie.

Chaconne op. 14. Improvisation ueber ein altes polnisches Kirchenlied. Improvisation für Orgel über ein altes polnisches Kirchenlied op. 38. Choral varié op. 50, hg. J. Erdman, Warszawa 2001.

Chlondowski A., Preludia na organy, Kraków 1992.

Chlondowski A., Wstęp do antologii polskiej muzyki organowej XIX i XX wieku, Archiwum Towarzystwa Salezjańskiego, Czerwińsk n/Wisłą, rkps.

Chlondowski A., Zbiór 225 tatwych preludiów na organy lub harmonium w najwięcej używanych tonacjach dur i moll, Poznań, 1960.

Dawna polska muzyka organowa, red. J. Grubich, Kraków 1968

Drewniak J., Kaptan - kompozytor. Dualizm powotania i twórczości ks. Idziego Ogiermana-Mańskiego (1900-1966), Warszawa 2007.

Erdman J., Organy, Warszawa 1989.

Feicht H., Dzieje polskiej muzyki religijnej w zarysie, [w:] Księga tysiaclecia katolicyzmu $w$ Polsce, t. 2, red. M. Rechowicz, Lublin 1969.

Fisharmonia, ww.pl.wikipedia.org/wiki/Fisharmonia (20.01.2012).

Furmanik J., Preludia II na organy, Lublin 2010.

Furmanik J., Tibi Domine. Preludia, z. 8, cz. 2, Lublin 2010.

Gołos J., Polskie organy i muzyka organowa, Warszawa 1972.

Gołos J., Z polskiej muzyki organowej XVI wieku, Kraków 1989. 
Heinemann M., Do liturgii i na koncert: Orgelverse Jana Jancy. Na siedemdziesiate urodziny kompozytora, tłum. M. Szoka, „Ruch Muzyczny” 19 (2003).

Hlond, Antoni, [w:] Encyklopedia muzyczna PWM, t. 4 H-J, red. E. Dziębowska, Kraków 1993.

Kruzel-Sosnowska M., Przedmowa, [w:] M. Sawa, Preludia organowe na temat polskich pieśni kościelnych, Kraków 2004.

Ludger Lohmann na organach kościota św. Jana w Tübingen, Musikproduction Dabringhaus und Grimm, 606 1104-2 (2002).

Machl T., Stowo od autora, [w:] T. Machl, Preludia na temat pieśni kościelnych, Kraków 1998.

Mato znane polskie utwory organowe XIX/XX wieku, red. J. Gołos, Warszawa 1990.

Morawska K., Historia muzyki polskiej. Renesans 1500-1600, Warszawa 1996.

Mrowiec K., Kultura muzyczna i pieśń kościelna, [w:] Historia Kościota w Polsce, t. 2, cz. 1, Poznań-Warszawa 1979, s. 712-717.

Ogierman-Mański I., Preludia na organy, Płock 2002.

Pawlak I., Muzyka liturgiczna po Soborze Watykańskim II w świetle dokumentów kościota, Lublin 2001.

Pietrzak W., Życie i twórczość kompozytorska Józefa Furmanika, Warszawa 1979, s. 241-267.

Pilch M., Jan Gawlas - śląki twórca ewangelickiej muzyki kościelnej, Wrocław 2008.

Poliński Aleksander, [w:] Podręczna encyklopedia muzyki kościelnej, opr. ks. G. Mizgalski, Poznań 1959.

Przybylski T., Gustaw Roguski (1839-1921), [w:] Zeszyty naukowe Akademii Muzycznej im. Stanistawa Moniuszki w Gdańsku, XXVII, Gdańsk 1988, s. 33-74.

Przybylski T., Józef Furmanik (1867-1953) i jego muzyka organowa, [w:] Organy i muzyka organowa, XII, Gdańsk 2003 (Prace Specjalne, 61), s. 306-315.

Przybylski T., Ksiądz Antoni Hlond (Antoni Chlondowski) (1884-1963) - kompozytor polskiej muzyki organowej i religijnej w I potowie XX wieku, [w:] Zeszyty naukowe Akademii Muzycznej im. Stanistawa Moniuszki w Gdańsku, XXV, Gdańsk 1986, s. 167-209.

Przybylski T., Pastoratki. Preludia na organy op. 63, z. 1, Kraków 2000.

Przybylski T., Polska pieśn kościelna w twórczości organowej kompozytorów od XVI wieku do Mieczystawa Surzyńskiego, [w:] Organy i muzyka organowa, X, Gdańsk 1997 (Prace Specjalne, 54), s. 135-150.

Przybylski T., Rok w pieśni kościelnej. Preludia organowe op. 42 na melodiach polskich pieśni osnute, Kraków 1999.

Przybylski T., Szkota organistowska w Przemyślu w latach 1916-1963 na tle ogólnego procesu ksztatcenia organistów w Polsce, [w:] W 50. rocznicę ogtoszenia encykliki papieża Piusa XII Musicae sacrae disciplina, Kraków 2005, s. 152 (Pro Musica Sacra, 2).

Przybylski T., Twórczość organowa Stefana Surzyńskiego (1855-1919), [w:] Organy i muzyka organowa, XI, Gdańsk 2000, s. 331 (Prace Specjalne, 54), s. 327-335. 
Przybylski T., Organistyka krakowska XVIII i XIX wieku oraz w latach międzywojennych XX wieku, [w:] Organy i muzyka organowa, XIII, Gdańsk 2006, s. 56 (Prace Specjalne, 71), s. 36-62.

Raport o stanie wiary. $Z$ ks. Kardynatem Josephem Ratzingerem rozmawia Vittorio Messori, przekł. Z. Oryszyna, weryf. i uzup. przekł. J. Chrapek, red. J. Klecel, Marki 1986.

Rutkowski B., Z zagadnień dzisiejszej muzyki kościelnej w Polsce, Muzyka Polska X (1935), nr 3-4, s. 259-270.

Rychling W., Zbiór Preludyj kościelnych na organ lub harmonium, z. 1, Kraków 1920.

Szoka M., Jan Janca. Organ Works, „Ruch Muzyczny” 21 (2002).

Szoka M., Twórczość organowa Jerzego Bauera - próba charakterystyki, [w:] Organy i muzyka organowa, V, Gdańsk 1984, s. 269 (Prace Specjalne, 33), s. 269-282.

Twórczość organowa Jana Gawlasa, [w:] Twórczość kompozytorów środowiska katowickiego, red. J. Bauman-Szulakowska, I. Bias, Katowice 1993 (Zeszyty Naukowe. Akademia Muzyczna im. Karola Szymanowskiego w Katowicach, 26).

Tyrała R., Cecyliański ruch odnowy muzyki kościelnej na ziemiach polskich do 1939 roku, Kraków 2010.

Wacholc M., Twórczość organowa ks. Antoniego Chlondowskiego, [w:] Zeszyty naukowe Akademii Muzycznej im. Stanistawa Moniuszki w Gdańsku, XXIX-XXX, Gdańsk 1991, s. 101-119.

Z polskiej muzyki organowej XIX i XX wieku, red. F. Rączkowski, J. Gołos, Kraków 1981. Zając A., Wybrane aspekty postugi organisty w spoteczności parafialnej, [w:] Muzyka organowa dzisiaj. Rola i zadanie organisty w Kościele, Kraków 2008, s. 65-88 (Pro Musica Sacra, 5). 